\title{
Implementation of editorial television data warehouse: Health and business news will keep high since pandemic Covid-19
}

\author{
Eugenius Kau Suni * and Yudo Devianto \\ Faculty of Computer Science, Universitas Mercu Buana, Jakarta, Indonesia.
}

World Journal of Advanced Engineering Technology and Sciences, 2021, 02(02), 001-020

Publication history: Received on 27 March 2021; revised on 29 April 2021; accepted on 01 May 2021

Article DOI: https://doi.org/10.30574/wjaets.2021.2.2.0037

\begin{abstract}
Data warehouse technology in the world of informatics can be applied in television editors to predict events in the future. The results of implementing a data warehouse in television editors since the Covid-19 pandemic shows that in the future, television coverage will still be dominated by health news 80.64 percent and economic news 65.61 percent. In Indonesia, legal and criminal news reports have also become a news trend as a result of these health and economic problems. The television editorial data warehouse was designed using Kimball's Nine-Step method and implementation using Microsoft SQL Server and Tableau. And to predict the news in the future analyzed using the Markov model. Apart from analyzing television news, this data warehouse is also capable know the performance of the television editorial team, namely the performance of news producers, reporters, and cameramen. The results of this data warehouse can be used by television management and chief editors to make informed strategic decisions.
\end{abstract}

Keywords: Television Editorial Decisions; News Television; Data Warehouse; SQL Server; Tableau; Markov Model.

\section{Introduction}

Data warehouse technology is used to manage large amounts of data collection to assist management in creating data warehouse strategy decisions [1]. The strength of a data warehouse lies in a large amount of data and statistical analysis [2]. Huge data sets are extracted, formatted, and stored in a data center to produce output in the form of analysis results [3]. So far, the data warehouse has been applied in the business of sales [4], finance and banking [5], agriculture [6], and also in the medical world [7].

This paper raises the application of data warehouse technology in the field of mass communication, especially in television reporting. This is possible because the news on television is always new and becomes news data that can be collected every day in large numbers very much [8]. Television news data sets can be further analyzed to determine the current news trend up to predictions for the future. The television editorial office is also handled by professionals who become a working team in presenting news to viewers, namely reporters, cameramen, and news producers. Analysis of the performance of the editorial team is also possible because of high work routines to present various news to the audience [8].

All the time, news in television editors has become a piece of passing information after the news was broadcast. Several television editors in Indonesia repackaged the broadcast in the form of an informational video clip which was republished on YouTube [9]. But the rest become information impressions that are fleeting and even forgotten. Moreover, news television broadcasts 24 hours per day. If the duration of each television news item is 3 minutes, so in one hour there are at least 20 news broadcasts on television [10]. It means in one day for television news 480 news stories are broadcast. If it is reduced by dialogue programs and news that are replayed, there will be approximately 400

\footnotetext{
* Corresponding author: Eugenius Kau Suni, Email: eugenius@mercubuana.ac.id

Faculty of Computer Science, Universitas Mercu Buana, Jakarta, Indonesia.
} 
news stories television is broadcast every day, and within a month about 12 thousand news stories are broadcast [11]. This is potential data that can be processed further for various interests of analysis include understanding the news trends for strategic decision making. In various literature studies, so far there is no instrument specifically built to manage the news that has been broadcast.

This television editorial data warehouse can also be used to help decision-making in television editors. Because all this time the only decision-making in television editors is through editorial meetings [12]. Television editorial meetings are usually held at least two times before a television program is aired, namely a pre-production meeting which contains the preparation of a coverage plan, and a post-production meeting which contains an examination of the production results or the results of the coverage team [13]. In particular, on television news programs, the news agenda discussed in a projection meeting (pre-production meeting) which took place at night to discuss the news agenda the next day. This meeting also discussed coverage plans related to news issues currently developing in the community. Furthermore, at the stage of frequent production meetings, there is a long discussion because it determines the end of a television program broadcast [14]. Here the results of the coverage that have been obtained will be was decided which news should be broadcast on a program with a limited duration. [15]. Data warehouse technology this development can support television editorial meetings so that decision-making related to reporting is more accurate and successful.

Previous research that became a reference in the continuation of this study discussed the analysis and design of a data warehouse to support television editorial decisions use the Nine-step Kimball method [16]. Then there is also a data warehouse to produce information systems required in filling out accreditation forms and producing analytical information for decision making in Informatics Study Program, Universitas Mercu Buana [17].

In this research, what is being done is to create a data warehouse to support decisions television, editorial staff. The data warehouse produced this time knows what news is the top issue and who the editorial team is most productive work on coverage and work on television news programs. The output of this data warehouse will be can be used to support the decisions of television editors in terms of determining newsworthy of broadcast and worthy of coverage, as well as to determine career advancement and promotion of the television editorial team. More than that, the news trend generated by this data warehouse can be used more continued by various parties in making other strategic decisions. Implementation of the data warehouse in the television editorial is the one first done and still needs to be further developed. Researchers built this data warehouse using the Nine-Steps method Kimball in the analysis and design stages [18], then the application implementation using SQL Server [19], and Tableau [20]. Next using the Markov Model in the analysis and prediction of future trends. The main data processing in the data warehouse about television news, then also the performance data of the television editorial team who routinely compile and present news to the audience. Editorial team television is meant here, namely cameraman, reporter, and news producer. To observe the accumulation of an event, as news collection, and employee performance, here using the Markov Process Model mathematical model that can predict events things to come [21], [22].

\section{Research Methods}

\subsection{Literature Study}

In conducting this research, the literature study is the first step taken to understand the object under study. Sekunder data collected are theories about data warehouse, data warehouse characteristics, including studying literature about Tableau and Microsoft SQL Server which will be used when implementing the data warehouse. Various theories and concepts are gathered from books, research journals, articles, and internet literature that have reputable reputations and trusted criteria. Several studies related to the object being studied also studied to determine the extent of the development of research on the object under study.

\subsection{Field Study}

This field study was conducted to collect primary data related to the object being studied. Researchers collect data about news television both in the television editorial office and real-time television news broadcasts. This field study is also to map the current problem faced and at the same time collect data and information to be used as material for implementing a data warehouse. The data that will be collected during this field study are television news data, reporter data and television cameramen, producer data television, and television editorial team performance data. 


\subsection{Implementation Of Data Warehouse With Tableau Dan Sql Server}

Furthermore, the implementation of the data warehouse uses Microsoft SQL Server and Tableau. Tableau is used to create data visualizations, data analysis, and reporting by combining data from various sources into the data warehouse. The implementation also uses the Microsoft SQL Server application where the exported data from various sources is processed using the Microsoft SQL Server analysis manager as a data warehouse.

The data needed to create a data warehouse is in the form of news data covered and broadcast news, as well as employee data. In the News Dimension, the attributes are News Code, News Headline, News Content, and News Status whether broadcast or not. Because usually a lot of news is covered, but little is shown. While in the Employee Dimension, the attribute consists of Number Main Employee, Name, Address, Phone Number, and Position whether as a reporter, cameraman, or producer. Because in the news television editorial at least these three positions are the main supporters of television editorial operations which really need attention in terms of improved capacity and career path.

\subsection{Prediction Of Future Trends With The Model Markov}

To calculate future predictions regarding news trends and employee performance, the Markov model takes into account every change from time to time to produce predictions of the future. Data changes in each dimension in the data warehouse recorded to be calculated using the Markov formula. The results of calculations using the Markov model will provide options for making strategic decisions to achieve success in the future.

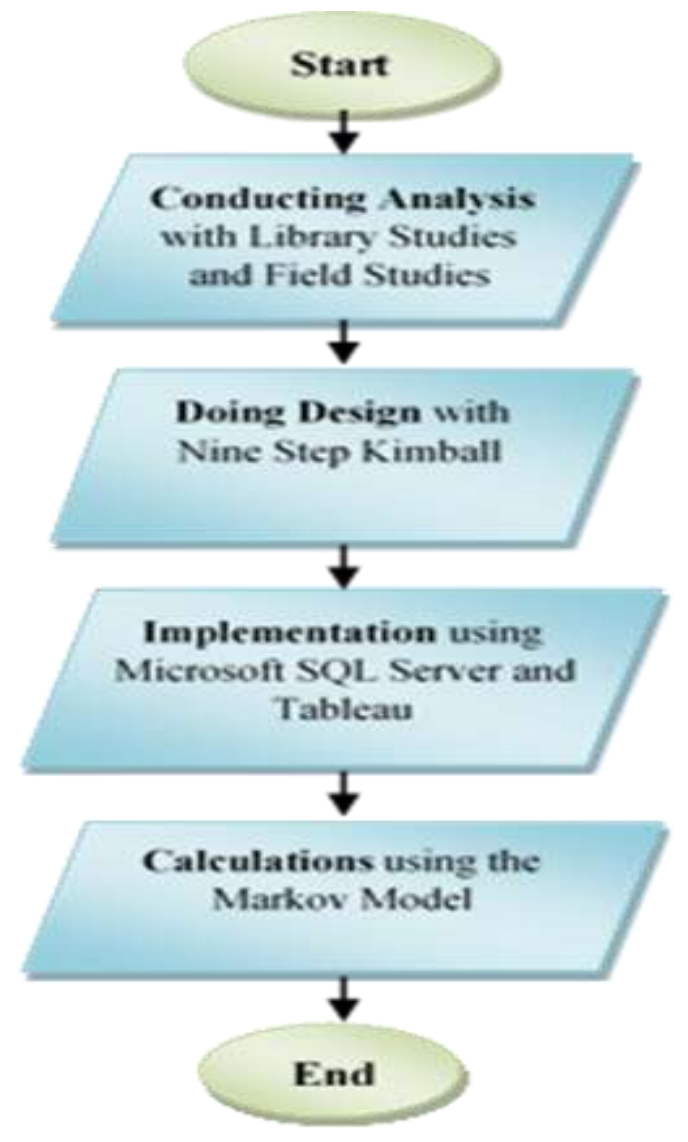

Figure 1 Research Stages Flowchart

\section{Results and discussion}

\subsection{Data Analysis}

The data collected during field studies and interviews are the editorial data of Kompas TV, consisting of television news data starting from television news, news data covered and broadcast, television news programs, and data on decisionmaking processes through meetings television editorial staff. Meanwhile, to measure performance, the data collected is 
related to reporter data, cameraman, and news producer data. Data retrieval is also carried out through the Kompas TV digital library and streaming television shows through the Kompas Tv site.

\subsection{System Requirements Analysis}

By studying the data and problems that exist in television editors, the system needs in making this television editorial data warehouse is as follows:

Table 1 Needs of Television Editorial Data Warehouse System

\begin{tabular}{|l|l|l|}
\hline No. & System Requirements & Actor \\
\hline 1 & $\begin{array}{l}\text { Covering the News, Submitting Video Coverage, and Writing Script } \\
\text { Television News. }\end{array}$ & Reporter and Cameraman \\
\hline 2 & $\begin{array}{l}\text { Reading News Coverage and Editing Television News Script as well } \\
\text { Broadcast Television News. }\end{array}$ & Producer \\
\hline 3 & $\begin{array}{l}\text { Seeing Periodically the Trend of Coverage and Reporter } \\
\text { Performance, Cameraman, and Producer and Print Report. }\end{array}$ & Admin and Editor Chief \\
\hline
\end{tabular}

\subsection{Data Warehouse Design}

This Data Warehouse design uses the 9-step Kimball method or the Kimball nine-step method with the following steps:

1. Determining the business process (Choosing the process). According to the results of observations and analysis, the business process established in relation to this study is the Television News Process.

Table 2 Choosing the Process

\begin{tabular}{|c|c|c|}
\hline Business Process & Description & The Function Involved \\
\hline Television News & $\begin{array}{c}\text { Gather all information television news broadcast } \\
\text { nor they are not showing, however, has been } \\
\text { covered }\end{array}$ & $\begin{array}{c}\text { Coverage Division (News } \\
\text { Gathering) and Division News } \\
\text { Production }\end{array}$ \\
\hline
\end{tabular}

2. Determining the granularity (Choosing the grain). In this section decide exactly what a fact table represented or represents. Here the level of detail of the data is determined which can be obtained from the dimensional model. So that the specified granularity is Television News Information.

Table 3 Choosing The Grain

\begin{tabular}{|l|l|l|}
\hline Grain & Description & The Business Process Involved \\
\hline $\begin{array}{l}\text { Television News } \\
\text { Information } \\
\text { Performance }\end{array}$ & $\begin{array}{l}\text { Television news information consists of News and } \\
\text { News Category. News is news that has been covered by } \\
\text { reporters and cameramen and processed until } \\
\text { displayed by the producer. Here beside the news, it is } \\
\text { also related to coverage and broadcast team } \\
\text { performance tv news. }\end{array}$ & Decision Editors Television. \\
\hline
\end{tabular}

3. Identifying and conforming the dimensions. The third step in designing a Data Warehouse is identifying dimensions associated with fact tables. From the identification results then can be determined the dimensions involved include: News Dimension, News Category Dimension, Producer Dimension, Reporter Dimension, Cameraman Dimension. 
Table 4 Identifying and Conforming The Dimensions.

\begin{tabular}{|l|l|l|}
\hline Dimension Table & Description & Grain \\
\hline News_Dimension & $\begin{array}{l}\text { News_Dimension equipped attributes: News_Code, } \\
\text { News_Title, News_Content, Category_Code, Duration }\end{array}$ & $\begin{array}{l}\text { Television } \\
\text { Information }\end{array}$ \\
\hline News_Category_Dimension & $\begin{array}{l}\text { News_Category_ Dimension equipped_attributes: } \\
\text { Category_Code, Category_Name }\end{array}$ & $\begin{array}{l}\text { Television } \\
\text { Information }\end{array}$ \\
\hline Producer_Dimension & $\begin{array}{l}\text { Producer_Dimension equipped attributes: Producer_Id, } \\
\text { Producer_Name, Address, and Phone }\end{array}$ & $\begin{array}{l}\text { Television } \\
\text { Information }\end{array}$ \\
\hline Reporter_Dimension & $\begin{array}{l}\text { Reporter_Dimension equipped attributes: Reporter_Id, } \\
\text { Reporter_Name, Address, and Phone }\end{array}$ & $\begin{array}{l}\text { Television } \\
\text { Information }\end{array}$ \\
\hline Cameraman_Dimension & $\begin{array}{l}\text { Cameraman_ Dimension equipped attributes: } \\
\text { Cameraman_Id, Cameraman_Name, Address, and Phone }\end{array}$ & $\begin{array}{l}\text { Television } \\
\text { Information }\end{array}$ \\
\hline
\end{tabular}

4. Choosing the fact. In the fact-sorting stage, a fact table is established which can implement all the grains used. In this case that fact specified are: Facts News, Fact Performance.

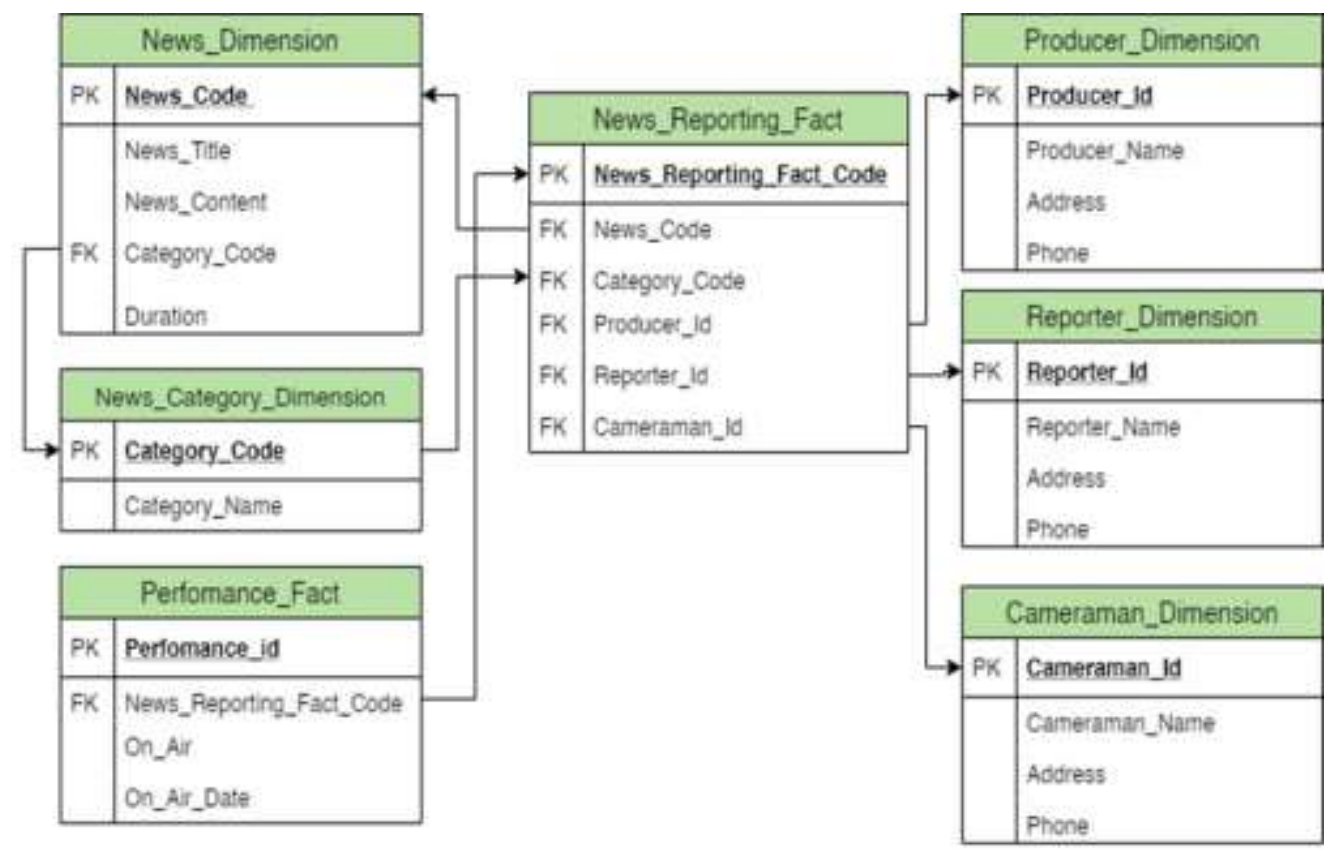

Figure 2 Schematic of Coverage Facts and Performance Facts

Table 5 Choosing the fact

\begin{tabular}{|c|c|c|}
\hline Fact & Description & Dimension \\
\hline $\begin{array}{l}\text { News Reporting } \\
\text { Fact }\end{array}$ & $\begin{array}{l}\text { News_Reporting_Fact contains information } \\
\text { television news that is covered and broadcast } \\
\text { along with the team that worked on it. }\end{array}$ & $\begin{array}{l}\text { News Dimension } \\
\text { News Category Dimension } \\
\text { Producer Dimension } \\
\text { Reporter Dimension } \\
\text { Cameraman Dimension }\end{array}$ \\
\hline Performance Fact & $\begin{array}{l}\text { Performance Fact contains a reporter, } \\
\text { cameraman, and producer are able to cover and } \\
\text { broadcast the news. }\end{array}$ & $\begin{array}{l}\text { News Dimension } \\
\text { Producer Dimension } \\
\text { Reporter Dimension } \\
\text { Cameraman Dimension }\end{array}$ \\
\hline
\end{tabular}


5. Storing pre-calculations in the fact table (Storing pre-calculations in the fact table). At this stage, the calculation process is carried out against the fact table, and stores the pre-calculation results, as follows: In Facts, the duration and number of news broadcasts need to be calculated and stored temporarily. Then in the Fact table, the performance of the number of news covered and aired needs to be taken into account as an important indicator of the performance of producers, reporters, and cameramen. Here each table is calculated and stored in advance where the recap of the data will become the data of a data warehouse, that is later in a certain period of time the results of a dynamic and varied report will be generated.

6. Complete the dimension tables (Rounding-out the dimension tables). This stage completes the dimension table with attributes and a commentary of the description.

Table 6 Rounding-out the dimension tables.

\begin{tabular}{|c|c|c|}
\hline Dimension/ Fact & Attribute & Data Type (Length) \\
\hline \multirow[t]{5}{*}{ News_Dimension } & News_Code & Varchar(15) \\
\hline & News_Title & Varchar(300) \\
\hline & News_Content & Longtext \\
\hline & Category_Code & $\operatorname{Int}(11)$ \\
\hline & Duration & Time \\
\hline \multirow[t]{2}{*}{ News_Category_Dimension } & Category_Code & $\operatorname{Int}(11)$ \\
\hline & Category_Name & $\operatorname{Varchar}(100)$ \\
\hline \multirow[t]{4}{*}{ Producer_ Dimension } & Producer_Id & Varchar(15) \\
\hline & Producer_Name & Varchar(100) \\
\hline & Address & Varchar(300) \\
\hline & Phone & Varchar(100) \\
\hline \multirow[t]{4}{*}{ Reporter_Dimension } & Reporter_Id & Varchar(15) \\
\hline & Reporter_Name & Varchar(100) \\
\hline & Address & Varchar(300) \\
\hline & Phone & Varchar(100) \\
\hline \multirow[t]{4}{*}{ Cameraman_ Dimension } & Cameraman_Id & $\operatorname{Varchar}(15)$ \\
\hline & Cameraman_Name & $\operatorname{Varchar}(100)$ \\
\hline & Address & Varchar(300) \\
\hline & Phone & Varchar(100) \\
\hline \multirow[t]{5}{*}{ News_Reporting_Fact } & News_Code & $\operatorname{Varchar}(15)$ \\
\hline & Category_Code & $\operatorname{Int}(11)$ \\
\hline & Producer_Id & $\operatorname{Varchar}(15)$ \\
\hline & Cameraman_Id & Varchar(15) \\
\hline & Reporter_Id & Varchar(15) \\
\hline \multirow[t]{4}{*}{ Performance_Fact } & Performance_Id & $\operatorname{Int}(11)$ \\
\hline & News_Code & Varchar(15) \\
\hline & On_Air & Boolean \\
\hline & On_Air_Date & Date \\
\hline
\end{tabular}


7. Determine the duration of the dimension (Choosing the duration of the dimension). This stage determines the duration of the database. For the manufacture of this data warehouse, it is determined that the duration of the data collected is 3 last years. The data is taken from the digital library of news recapitulation and employee recapitulation data of Kompas TV, especially producers, reporters, and cameraman and impressions on the Kompas Tv streaming site.

8. Tracing the dimensions including slowly changing dimension (Tracking slowly changing dimension). This stage takes into account slow, traceable dimensional changes. In the Kompas TV editorial staff, the employee data are producers, as well as reporters, and cameramen can always change slowly because of a promotion, assignment, or job change (resign).

9. Deciding the query priorities and the query modes (Deciding the query priorities and the query modes). This stage uses physical design to produce a data warehouse that is ready to be implemented. Here also the query specifies-query or report (reporting) to be able to display the data desired by the user. In this design, a data warehouse is built to display the most covered and broadcast news information, Reporter and Cameraman who cover the most news, The producer who works on and broadcasts the most news. The amount of news that is covered and broadcast will show the most issues strong and attractive and is in the public's attention, and the trend will be seen in a certain period of time. While reporters, cameramen, and producers with the amount of news covered and worked on and broadcast as indicators of determining performance. Query results or reporting like this can be used by policymakers or leaders in making strategic decisions.

\subsection{Implementation of Data Warehouse}

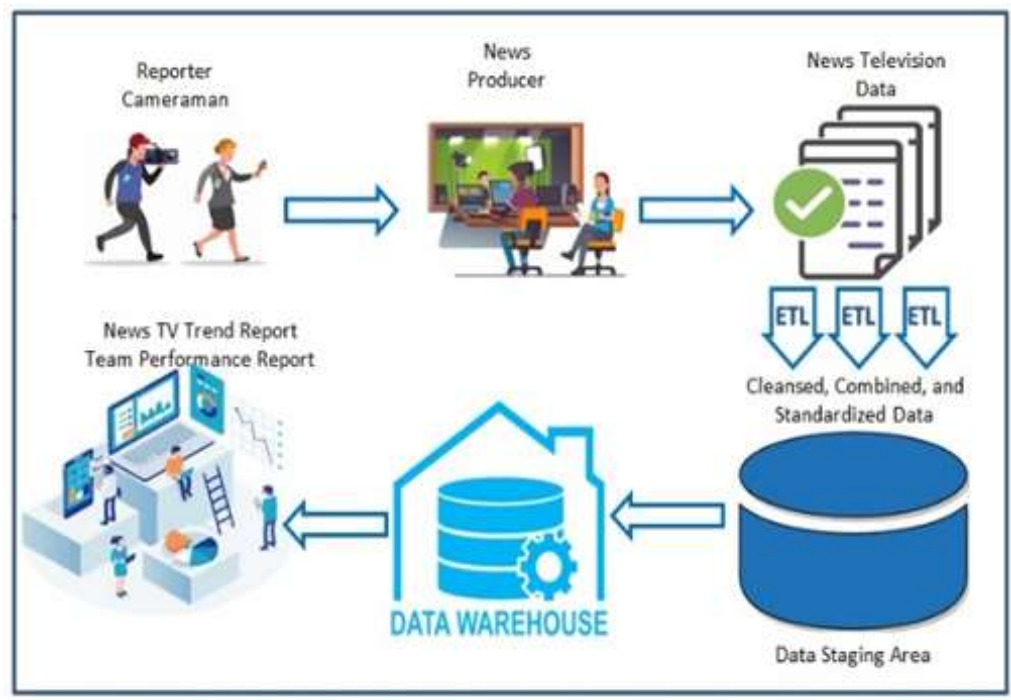

Figure 3 Data Warehouse News Television

Figure 3 above shows the television editorial data warehouse that was built, where the data stored is in the form of coverage by reporters and cameraman. This coverage was further processed by a news producer who edited the narrative along with video images and broadcast it on broadcast television news. The television news data is then stored as news coverage data as well as broadcast news data. The news data stored with data from the television editorial team, namely data from cameramen, reporters, and producers. This is where the data is grouped and processed further into the tables including the ETL process. ETL hassle data is entered into the data staging area to be stored in an editorial data warehouse television. The results of this data warehouse can be retrieved periodically in the form of news trend reports within a certain period of time, and report on the performance of the television editorial team in a certain period of time. The output of this data warehouse is in the form of data visualization in the form of graphs, diagrams, and an easy-to-understand format for periodic reports.

\subsection{Database Implementation With Sql Server}

In this data warehouse implementation, the database is built using MySQL and SQL Server. Starting with creating tables as a dimension in the data warehouse. For example, the Create Table NewsDimension can be seen in the source code below. 


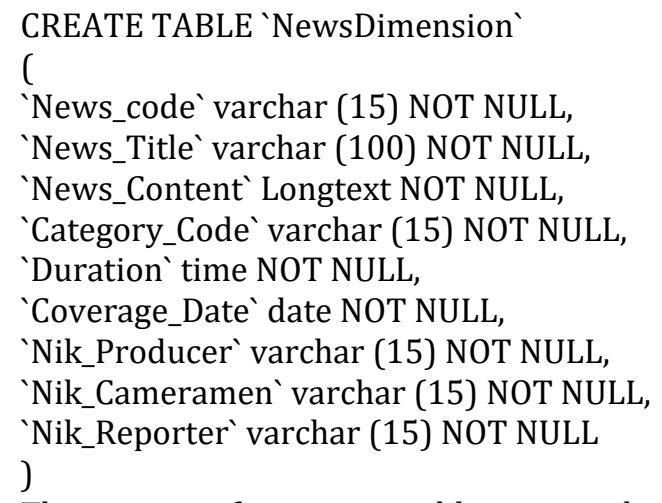

The process of creating a table is carried out on all dimensions and facts which will be linked to each other in a data warehouse database.

\subsection{Implementation of Data Warehouse System Applications}

To make it easier for the editorial team and admin to input data, a data warehouse application was built, so that the input process data can be done by each admin or authorized user. The secretariat team in the television editorial team can register as a given user the right of access to perform the data input process of news summaries and news coverage every day. Even reporters and producers are given access rights as users to type news and edit news script that will be broadcast on television, directly in the data warehouse system. The application is built using Code Igniter an opensource PHP framework and uses the view model controller (MVC). Code igniter makes it very easy to help websitebased systems with the structured and easy syntax used and the level of safety is guaranteed. Code igniter is superior in managing the backend while managing the frontend using a bootstrap which is known to be reliable to give an attractive website frontend appearance. As a trial, this data warehouse system application can be accessed online through the website https://datawarehouse.ranselpro.com/ and will produce a login display like the image below.

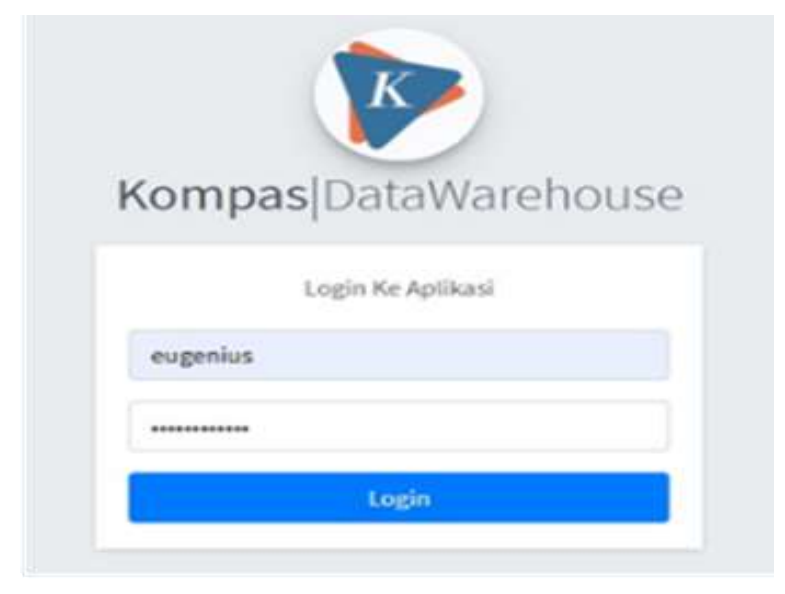

Figure 4 Login Data Input in the Data Warehouse System

In the Figure above, each user who is granted access rights must have a user ID and password to be able to log into the data warehouse system.

If the login is successful, the user can immediately enter the data which will be stored in the database. For example, in the television news input process, it will be shown as shown below. 


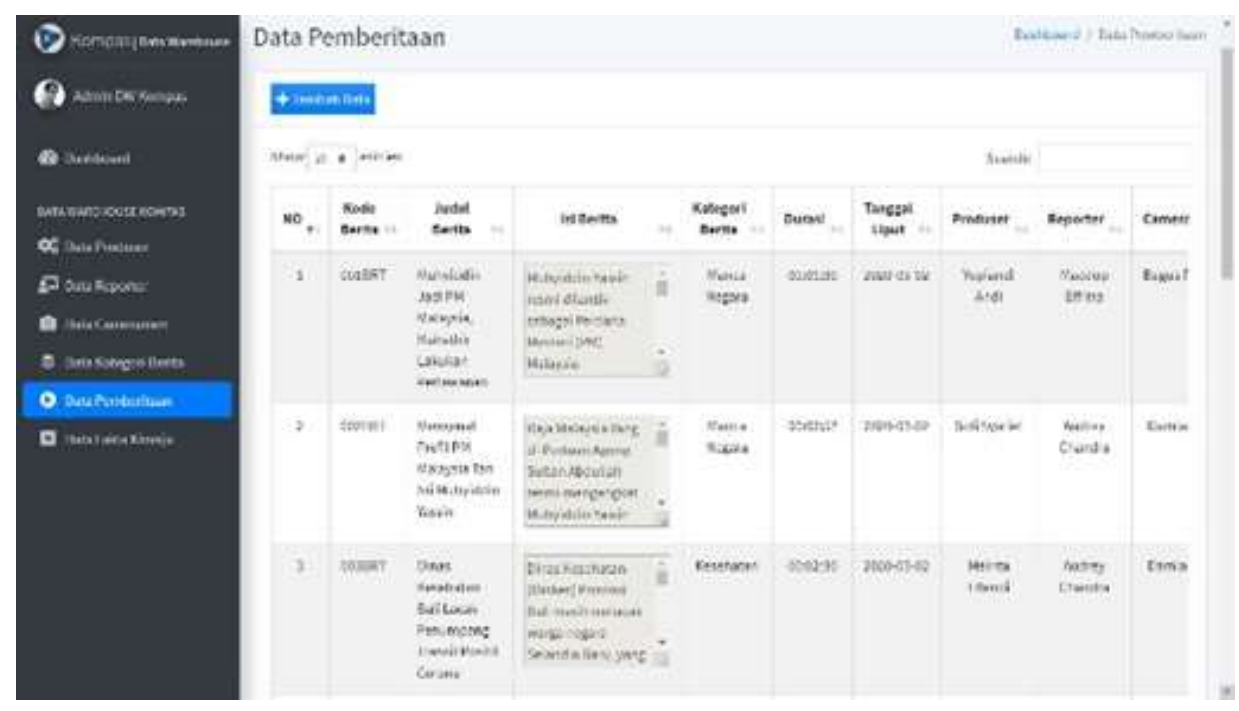

Figure 5 Display of News Data

Here an admin can add news data that is covered by clicking the Add Data button and then inputting the data news ranging from News Code, News Title, News Content, News Category, Duration, Date Coverage, Producer who worked on it, including reporters and cameramen who cover it. This data input process can be carried out by an admin appointed in the television editorial or carried out by an executive producer so that the data entered is under the actual data while avoiding adding data incorrectly for the purpose to improve one's performance.

After clicking the Add Data button a display interface will appear as shown below to be able to input data-television news data.

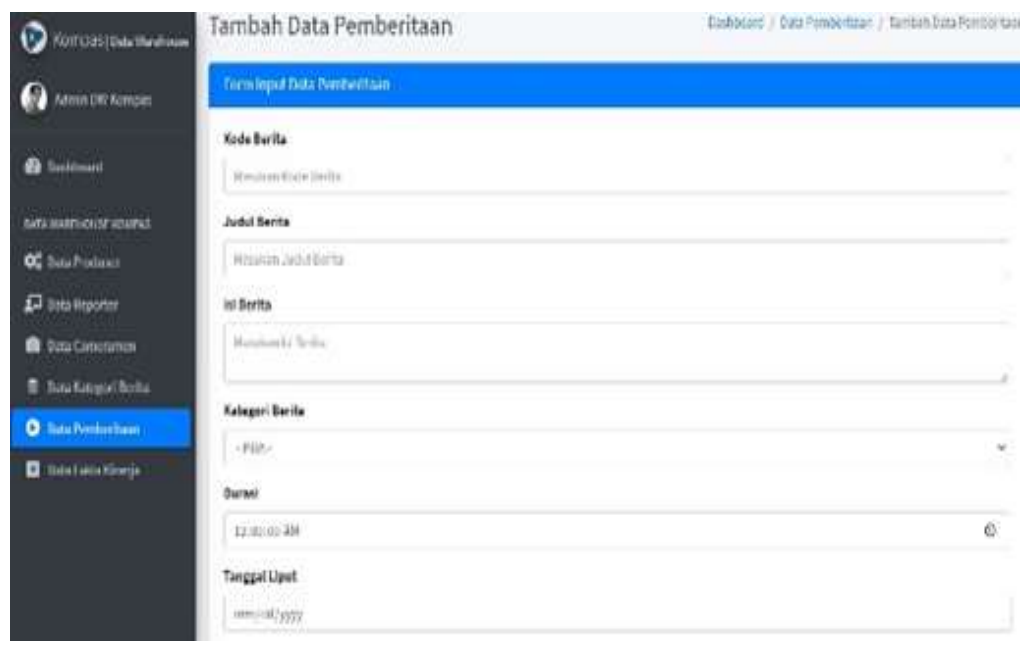

Figure 6 Add News Data Display

In addition to news data, the image above is also shown on the dashboard, where an admin can add data from reporters, cameramen, producer, and news categories, as well as updating the performance of the editorial team. Every superior, rather than a reporter, cameraman, and producer can update data to find out exactly the development of the team's performance, including updating the news that has been covered and aired. 


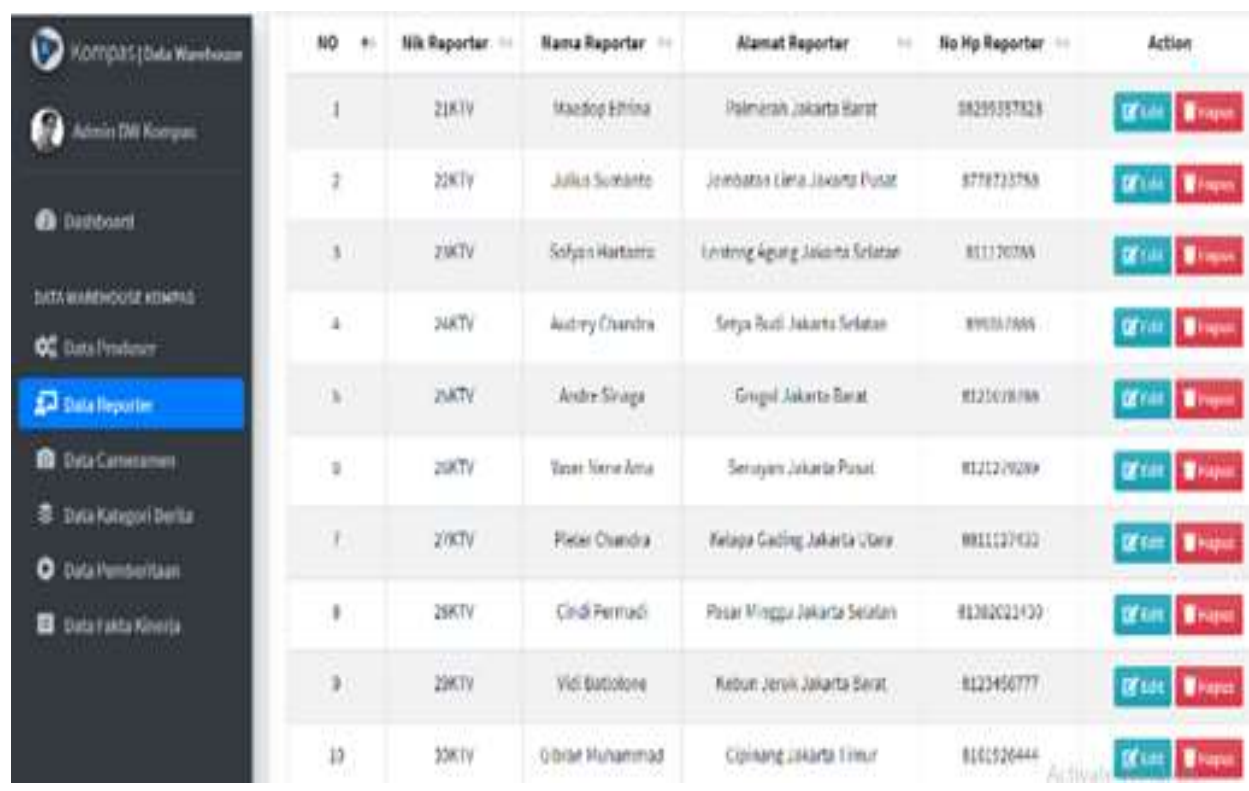

Figure 7 Display Add News Data

Figure 7 above shows a summary of reporter's data on Kompas TV which can be updated for any changes such as adding reporter data or change reporter data. The data recap above will be stored in a SQL Server database for a certain period of time as more and more can be moved into the data warehouse by a data warehouse manager through the Extraction process, Transformation, and Load (ETL).

\subsection{ETL Implementation}

In this Extraction, Transformation, and Load (ETL) process using SQL Server Integration Services (SSIS) tools, and for the Editor using Microsoft Visual Studio 2017. SSIS is used to integrate data on the ETL process which is also automatic perform database updates and maintenance of SQL Server. SSIS uses Microsoft Visual Studio 2017 which is implemented here also allows the ETL process to be carried out free of charge, especially in the trial activities of developing a data warehouse.

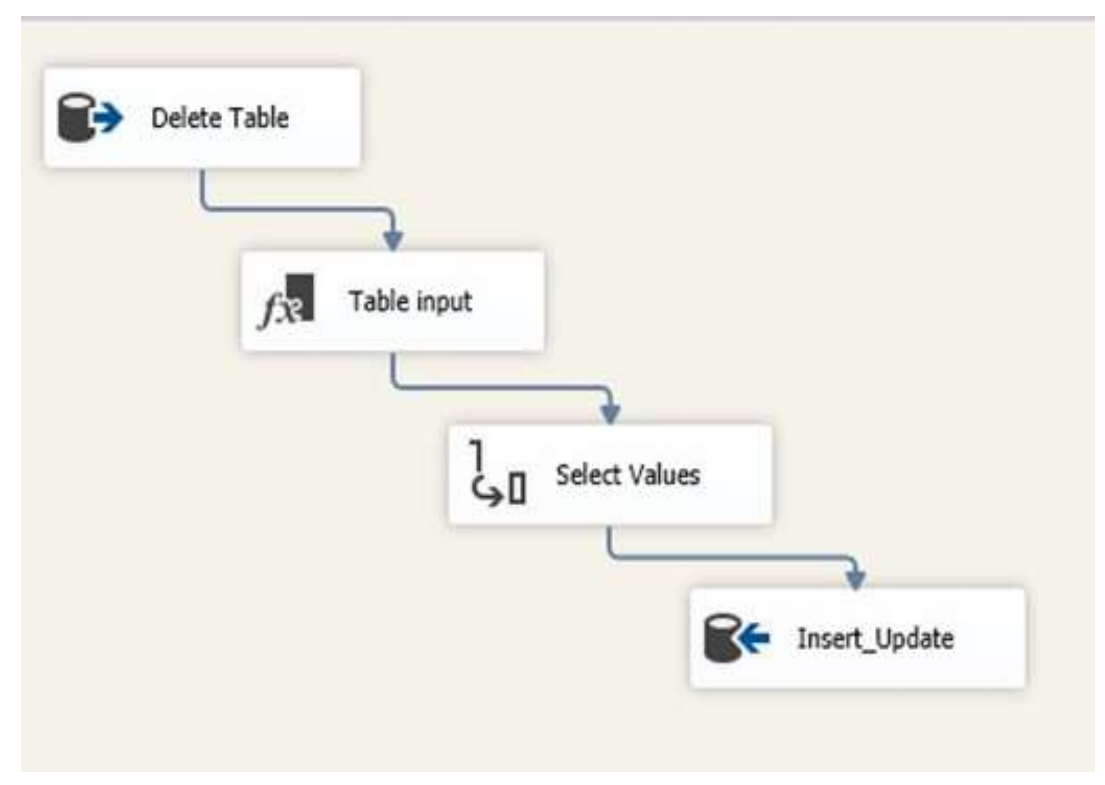

Figure 8 ETL Process View with SSIS Tools

Figure 8 above shows the ETL process with SSIS tools, where in the process of storing data into the data warehouse, it begins with Delete Table to first empty the existing data. Next, the Input Table is in the form of data retrieval from 
MySQL, followed by Select Values, which is selecting the part or fields to be filled in to be displayed, and then Insert_Update as input to the system data warehouse storage.

\subsection{Data Warehouse Visualization Results With Tableau}

To make a report (reporting) as one of the outputs of the data warehouse, a more interesting and easy data visualization is needed understood by decision makers. Data visualization here uses tableau.

\section{Kompas TV Performance Fact}
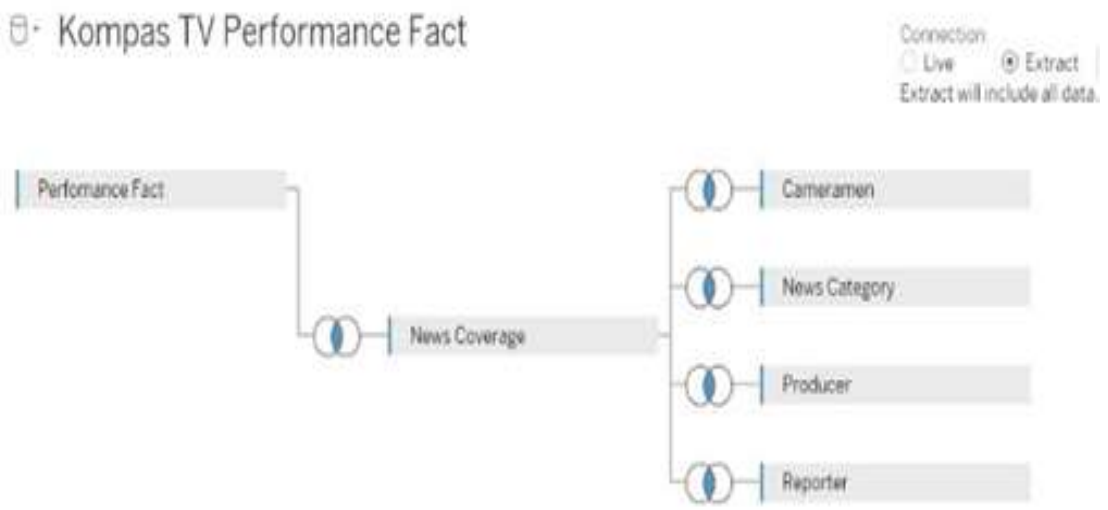

Figure 9 Dimensional and Fact Data Process Using Tableau

The figure 9 above shows the tableau software processing data on dimensions and facts that will produce data visualization interesting and varied. Furthermore, the results of data visualization on the performance of the television editorial team and news trends.

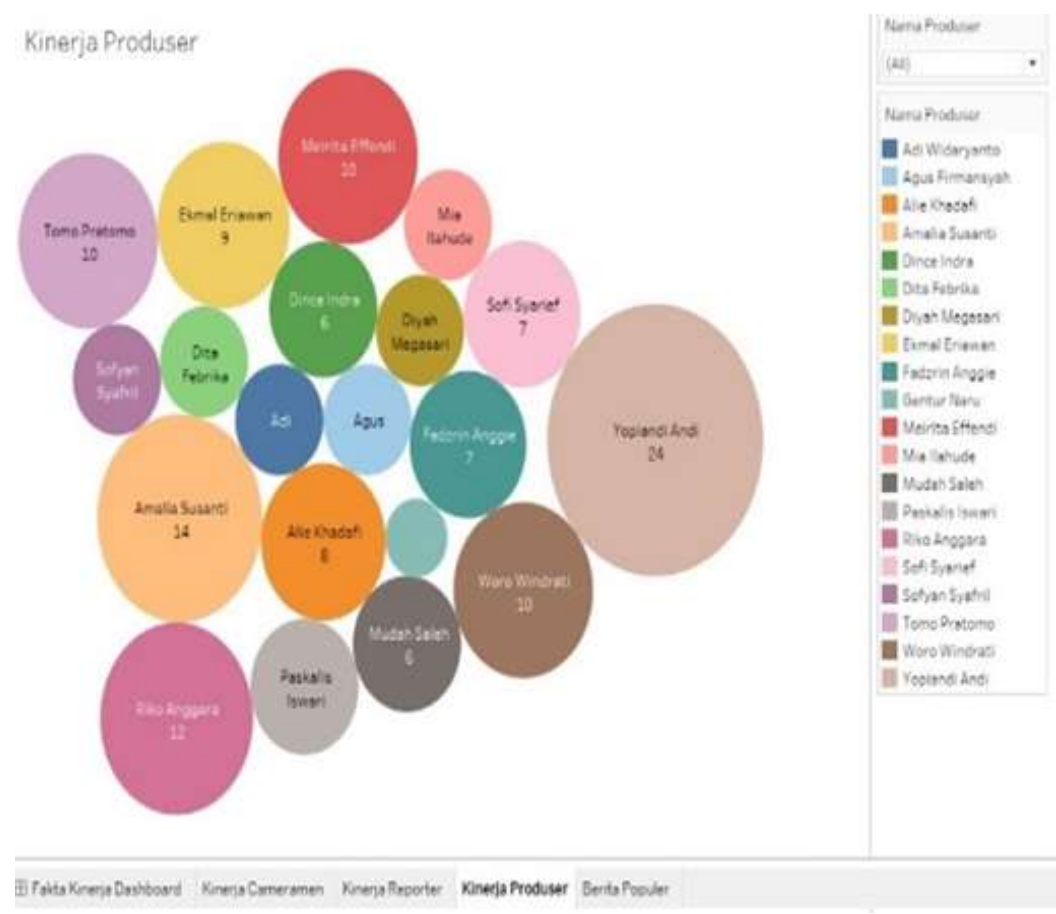

Figure 10 Producer Performance Data Visualization 
The figure 10 above shows the producer with the best performance on behalf of Yopiandi Andi, followed by Amalia Susanti, and Riko Anggara. This result can provide input for television editorial management to make further decisions related to promotions and career paths.

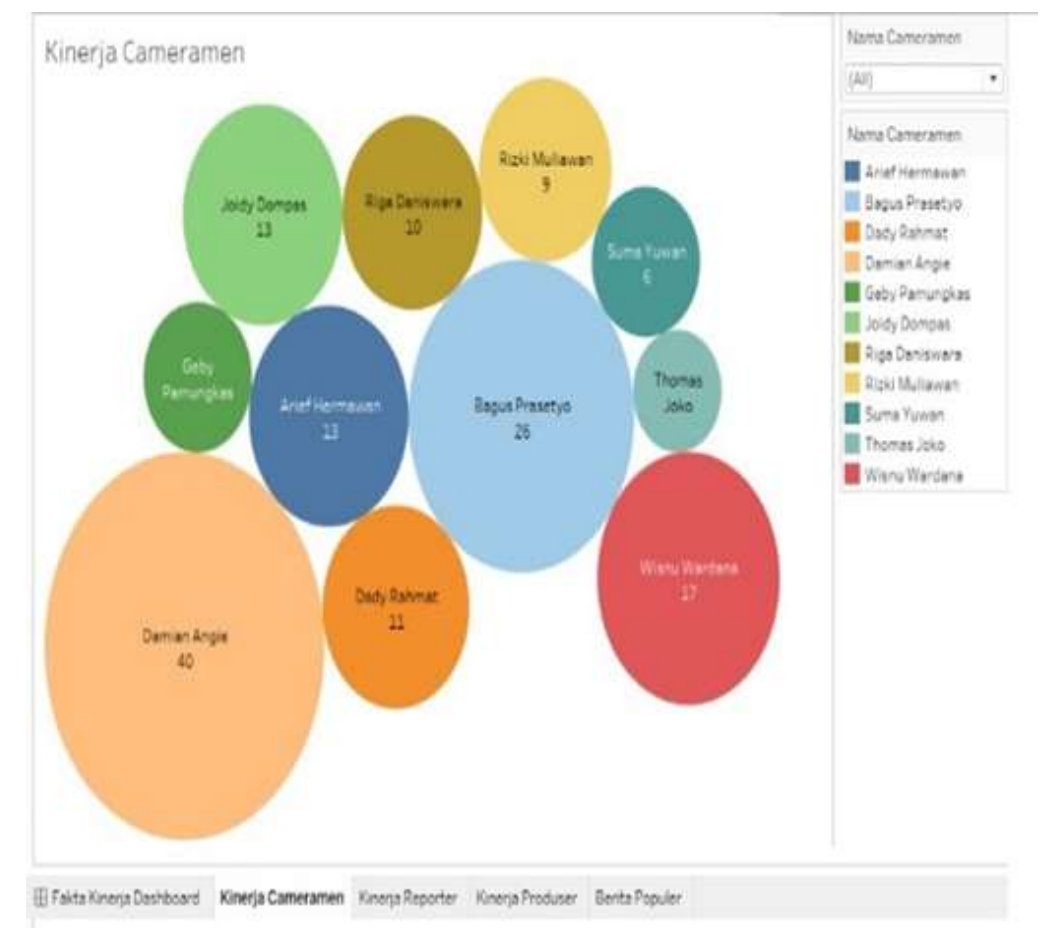

Figure 11 Cameraman's Performance Data Visualization

The results of the data warehouse visualization of the cameraman's performance show that the cameraman on behalf of Damian Angie is in the performance position the best, followed by Bagus Prasetyo, and Wisnu Wardana.

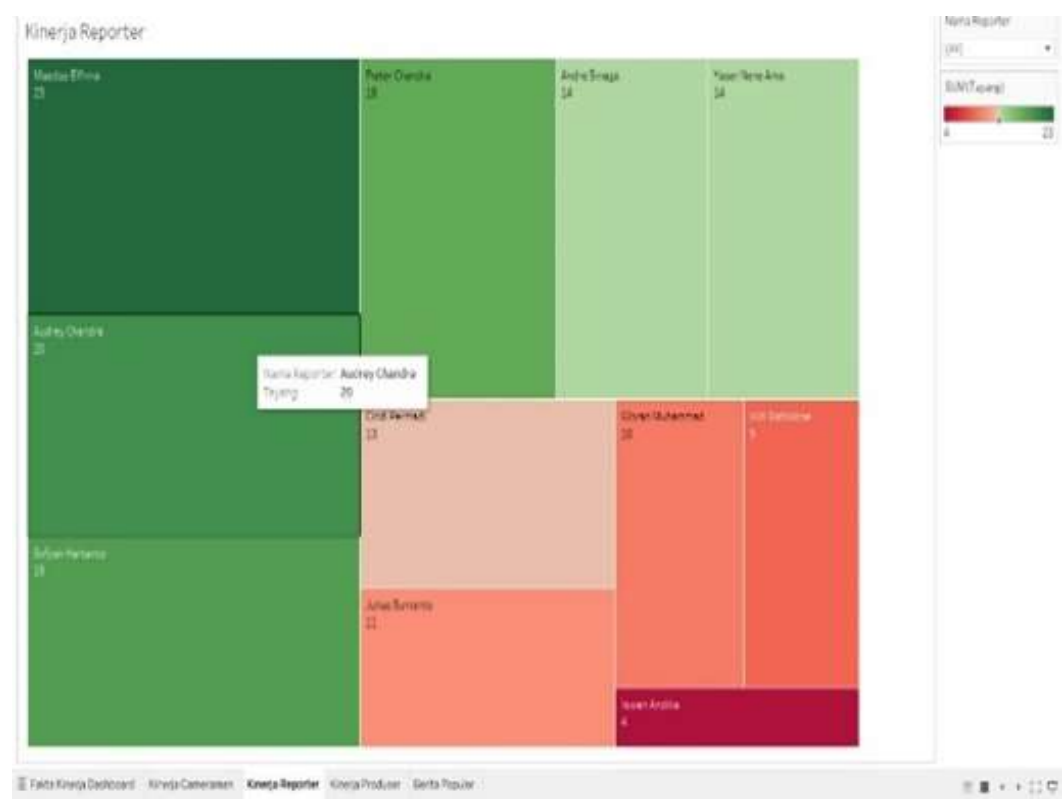

Figure 12 Reporter Performance Data Visualization

The figure 12 above shows the performance of reporter Maedop Elfrina in the highest position, followed by Audre Chandra, and Sofyan Hartanto. Furthermore, the results of the visualization of the news data in the television editorial. 


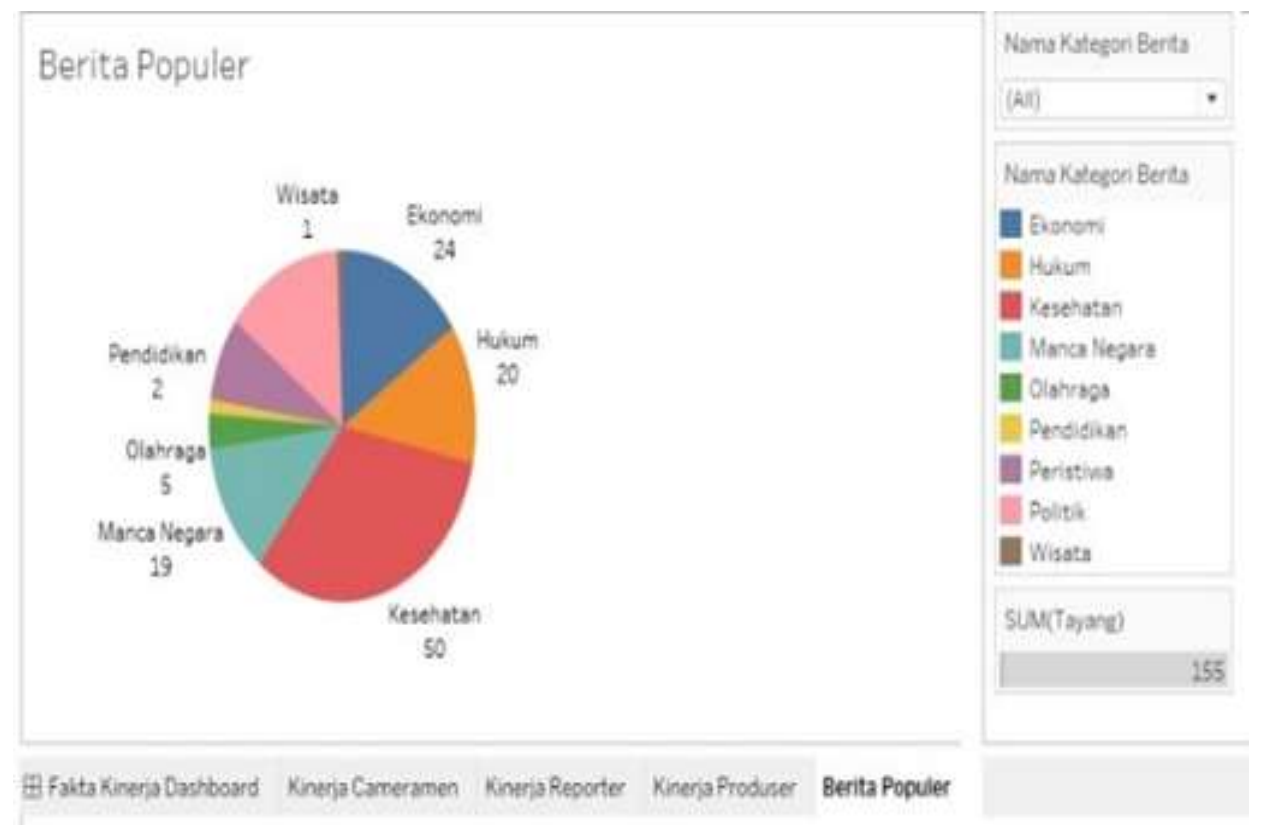

Figure 13 Visualization of News Trend Data

The figure 13 above shows that the news that is most covered and aired on television is about health issues, followed by Economic news, and the third position is Legal news. If we look deeper into the health news which ranks the highest is news about the corona virus or covid-19 which is of national concern and world attention. The second position is where the economic news governments and the world community face economic constraints as a direct result of these health problems. And in Indonesia Legal news especially the increase in crime received a high portion of the coverage. Criminal cases that occur also related to economic difficulties due to the impact of the corona virus or covid-19.

After seeing the data warehouse results above, then predict future trends with the Markov model. Data analyzed on data warehouse is taken from the main news data in period I and period II, about news categories, performance of producers, reporters, to cameramen. In the first period, 86 stories were taken and published by producers, reporters and cameramen. And then on period second also taken 86 news to be able to calculate the transition probability as a trend of news and performance.

Table 7 Illustrates the news data in period I and the changes in period II

\begin{tabular}{|c|c|c|c|c|c|c|c|c|c|c|c|c|}
\hline \multirow[b]{2}{*}{ NerisCategay } & \multirow[b]{2}{*}{ PendI } & \multicolumn{5}{|c|}{ Ineasfrum } & \multicolumn{5}{|c|}{ Derrease To } & \multirow[b]{2}{*}{ Pendil } \\
\hline & & Hath & Buxiess & Politos & $\begin{array}{l}\text { Lavad } \\
\text { Ome }\end{array}$ & $\begin{array}{l}\text { Word } \\
\text { Neils }\end{array}$ & Heallh & Bisness & Politos & $\begin{array}{l}\text { Lavad } \\
\text { Come }\end{array}$ & $\begin{array}{l}\text { Wadd } \\
\text { Nens }\end{array}$ & \\
\hline Heath & 26 & 0 & 2 & 7 & 2 & 2 & 0 & 2 & 1 & 0 & 0 & 36 \\
\hline Buxinss & 19 & 2 & 0 & 4 & 1 & 1 & 2 & 0 & 2 & 0 & 0 & 3 \\
\hline Potass & 17 & 1 & 2 & 0 & 3 & 3 & 1 & 4 & 0 & 6 & 0 & 9 \\
\hline Lavadome & 12 & 0 & 0 & 6 & 0 & 2 & 2 & 1 & 3 & 0 & 5 & 9 \\
\hline MadiNens & 12 & 0 & 0 & 0 & 5 & 0 & 2 & 1 & 3 & 2 & 0 & 9 \\
\hline Total & 86 & & & & & & & & & & & 86 \\
\hline
\end{tabular}

The table 7 illustrates the news data in period I and the changes in period II, where each news category in period I experienced increase and also decrease in period II. Here it is also very clear that the increase in news in a news category increases from any category and reduced to another news category. Changes in data for period I and period II will be used to perform the analysis Furthermore. 
Table 8 Depicts the producer performance data in period I, the news has changed in period II.

\begin{tabular}{|c|c|c|c|c|c|c|c|c|c|c|c|c|}
\hline \multirow[b]{2}{*}{ Produrs } & \multirow[b]{2}{*}{ PrandI } & \multicolumn{5}{|c|}{ Inper From } & \multicolumn{5}{|c|}{ Derease To } & \multirow[b]{2}{*}{ PrandII } \\
\hline & & Yopine & Amals & Riko & Menth & Wro & Yopand & Amala & Rklo & Nenta & Waro & \\
\hline Yopini & 24 & 0 & 4 & 4 & 4 & 0 & 0 & 4 & 3 & 2 & 1 & 26 \\
\hline Ambia & 19 & 4 & 0 & 2 & 5 & 0 & 4 & 0 & 2 & 2 & 2 & 20 \\
\hline Rkko & 13 & 3 & 2 & 0 & 3 & 1 & 4 & 2 & 0 & 0 & 0 & 16 \\
\hline Menth & 18 & 2 & 2 & 0 & 0 & 2 & 4 & 5 & 3 & 0 & 2 & 10 \\
\hline Waro & 12 & 1 & 2 & 0 & 2 & 0 & 0 & 0 & 1 & 2 & 0 & 14 \\
\hline Total & 86 & & & & & & & & & & & 86 \\
\hline
\end{tabular}

The table 8 depicts the producer performance data in period I, the news has changed in period II. There are producers whose performance increased but there was a decline in terms of quantity of work handled. This data change can be used to perform analysis probability in the future.

Table 9 Shows the performance data of reporters in period I experienced changes in period II.

\begin{tabular}{|c|c|c|c|c|c|c|c|c|c|c|c|c|}
\hline \multirow[b]{2}{*}{ Reptr } & \multirow[b]{2}{*}{ Penol } & \multicolumn{5}{|c|}{ Imers from } & \multicolumn{5}{|c|}{ Derpesere To } & \multirow[b]{2}{*}{ Penondi } \\
\hline & & Meadp & Auntey & Sofyn & Pitar & Cani & Naropo & Audey & Sofyan & Pater & Cini & \\
\hline Mraiop & 22 & 0 & 4 & 2 & 4 & 1 & 0 & \& & 2 & 3 & & 22 \\
\hline Autry & 20 & 5 & 0 & 1 & 2 & 4 & 4 & 0 & 5 & 2 & 4 & 17 \\
\hline Sotjan & 15 & 2 & 5 & 0 & 0 & 1 & 2 & 1 & 0 & 0 & 0 & 20 \\
\hline Piter & 16 & 3 & 2 & 0 & 0 & 1 & 4 & 2 & 0 & 0 & . & 15 \\
\hline Cind & 13 & 1 & 4 & 0 & 1 & 0 & 1 & 4 & 1 & 1 & 0 & 12 \\
\hline Total & 86 & & & & & & & & & & & 86 \\
\hline
\end{tabular}

The table 9 shows the performance data of reporters in period I experienced changes in period II, where the amount of coverage for 86 headlines in period I was spread over the five reporters above and in period II experienced changes in the distribution of data. Because there are reporters whose coverage increases and some are reduced because the coverage has been handled by other reporters.

Table 10 Shows the amount of coverage handled by cameramen in period I and the amount of coverage handled by cameramen in period II

\begin{tabular}{|c|c|c|c|c|c|c|c|c|c|c|c|c|}
\hline \multirow[b]{2}{*}{ Camremry } & \multirow[b]{2}{*}{ PrindI } & \multicolumn{5}{|c|}{ Inres From } & \multicolumn{5}{|c|}{ Dercese To } & \multirow[b]{2}{*}{ PenodII } \\
\hline & & Damin & Begrs & Wisu & Jaidy & Anf & Daminan & Bagus & Wisu & baty & Anff & \\
\hline Damin & 27 & 0 & 4 & 3 & 4 & 1 & 0 & 10 & 4 & 3 & 2 & 20 \\
\hline Bagris & 17 & 10 & 0 & 2 & 1 & 0 & 4 & 0 & 3 & 3 & 1 & 19 \\
\hline Wisu & 15 & 4 & 3 & 0 & 1 & 0 & 3 & 2 & 0 & 0 & 1 & 17 \\
\hline Jody & 15 & 3 & 3 & 0 & 0 & 0 & 4 & 1 & 1 & 0 & 0 & 15 \\
\hline Anef & 12 & 2 & 1 & 1 & 0 & 0 & 1 & 0 & 0 & $\theta$ & 0 & 15 \\
\hline Total & 86 & & & & & & & & & & & 86 \\
\hline
\end{tabular}


The table 10 shows the amount of coverage handled by cameramen in period I and the amount of coverage handled by cameramen in period II. There is an increase or decrease in the amount of coverage by a cameraman who will be further analyzed to obtain trend results the performance of the aforementioned cameraman.

Furthermore, by observing the initial condition data and its changes in the condition of period II, the probability value of the news trend can be obtained calculated with the results as shown in the following table.

Table 11 Observing the initial condition data and its changes in the condition of period II.

\begin{tabular}{|l|l|l|l|l|l|}
\hline News Category & \multicolumn{4}{|l|}{ Period II } & \multicolumn{5}{l|}{} \\
\hline Period I & Health & Business & Politics & Law and Crime & World News \\
\hline Health & 0.884615 & 0.076923 & 0.038462 & 0 & 0 \\
\hline Business & 0.105263 & 0.789474 & 0.105263 & 0 & 0 \\
\hline Politics & 0.411765 & 0.235294 & 0 & 0.352941 & 0 \\
\hline Law and Crime & 0.166667 & 0.083333 & 0.25 & 0.083333 & 0.416667 \\
\hline World News & 0.166667 & 0.083333 & 0.25 & 0.166667 & 0.333333 \\
\hline
\end{tabular}

From the calculation results in the table above, it is known that the probability of surviving news on health news is 88.46 percent, economic news78.94 percent, political news 0 percent, legal and criminal news 8.33 percent, and world news 33.33 percent. The results of the table above can be rewritten in the form of a matrix P1 for the news trend are as follows.

$$
\mathrm{Pl}^{\mathrm{l}}=\left(\begin{array}{ccccc}
0.884615 & 0.076923 & 0.038462 & 0 & 0 \\
0.105263 & 0.789474 & 0.105263 & 0 & 0 \\
0.411765 & 0.235294 & 0 & 0.352941 & 0 \\
0.166667 & 0.083333 & 0.25 & 0.083333 & 0.416667 \\
0.166667 & 0.083333 & 0.25 & 0.166667 & 0.333333
\end{array}\right)
$$

And to determine the news trend in the future, calculations are made to determine the value from P2 as follows:

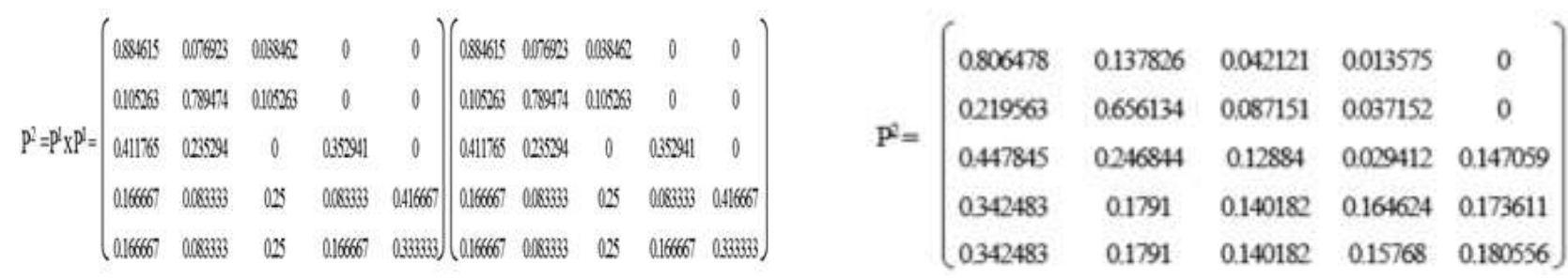

The results of the matrix calculation above P2 show that in the future health news is still the highest with an estimated 80.64 percent, followed by economic news at 65.61 percent, while other news is relatively low. During the Covid-19 pandemic, the news was still dominated by health and economic news.

The next analysis and calculation are carried out on the performance data of producers in the news television editorial, where the data in the period I and period II are used to calculate the probability value, with the results as in the following table 12. 
Table 12 Calculate the probability value.

\begin{tabular}{|c|c|c|c|c|c|}
\hline Producer & Period II & & & & \\
\hline Period I & Yopiandi & Amalia & Riko & Meirita & Woro \\
\hline Yopiandi & 0.583333 & 0.166667 & 0.125 & 0.083333 & 0.041667 \\
\hline Amalia & 0.210526 & 0.473684 & 0.105263 & 0.105263 & 0.105263 \\
\hline Riko & 0.307692 & 0.153846 & 0.538462 & 0 & 0 \\
\hline Meirita & 0.222222 & 0.277778 & 0.166667 & 0.222222 & 0.111111 \\
\hline Woro & 0 & 0 & 0.083333 & 0.166667 & 0.75 \\
\hline
\end{tabular}

The results of the table 12 above can be rewritten in the form of the P1 matrix for the producer performance trends as follows:

$$
\mathrm{pl}^{\mathrm{i}}=\left(\begin{array}{ccccc}
0.583333 & 0.166667 & 0.125 & 0.083333 & 0.041667 \\
0.210526 & 0.473684 & 0.105263 & 0.105263 & 0.105263 \\
0.307692 & 0.153546 & 0.538462 & 0 & 0 \\
0.223222 & 0.27778 & 0.166667 & 0.223202 & 0.111111 \\
0 & 0 & 0.083333 & 0.166667 & 0.75
\end{array}\right)
$$

And to determine the performance trend of producers in the future, calculations are made to find outthe value of P2 is as follows:

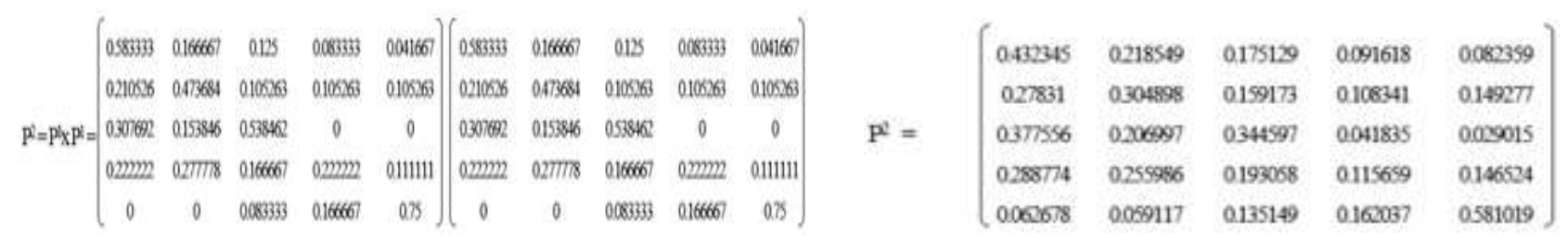

The results of the calculation of the P2 matrix show that in the future the performance of Yopiandi producers will be maintained at 43.23 percent, followed by producer Riko with 34.45 percent for fixed performance, and Amalia with 30.48 percent for stability.

The next analysis and calculation are carried out on the performance data of television news reporters, where the data is in the period I and period II is used to calculate the probability value, with the results as shown in the following table.

Table 13 The performance data of television news reporters.

\begin{tabular}{|c|c|c|c|c|c|}
\hline Reporter & Period II & & & & \\
\hline Period I & Maedop & Audrey & Sofyan & Pieter & Cindi \\
\hline Maedop & 0.5 & 0.227273 & 0.090909 & 0.136364 & 0.045455 \\
\hline Audrey & 0.2 & 0.25 & 0.25 & 0.1 & 0.2 \\
\hline Sofyan & 0.133333 & 0.066667 & 0.8 & 0 & 0 \\
\hline Pieter & 0.25 & 0.125 & 0 & 0.5625 & 0.0625 \\
\hline Cindi & 0.076923 & 0.307692 & 0.076923 & 0.076923 & 0.461538 \\
\hline
\end{tabular}


The results of the table 13 above can be rewritten in the form of a P1 matrix for the trend of reporter performance as follows.

$$
\mathrm{Pl}^{1}=\left(\begin{array}{ccccc}
0.5 & 0.227273 & 0.090909 & 0.136364 & 0.045455 \\
02 & 0.25 & 0.75 & 0.1 & 0.2 \\
0.133333 & 0.066667 & 0.8 & 0 & 0 \\
0.75 & 0.125 & 0 & 0.6625 & 0.0625 \\
0.076923 & 0.307692 & 0070223 & 0.076023 & 0.461538
\end{array}\right)
$$

And to determine the trend of the reporter's performance in the future, calculations are made to determine the value from P2 as follows:

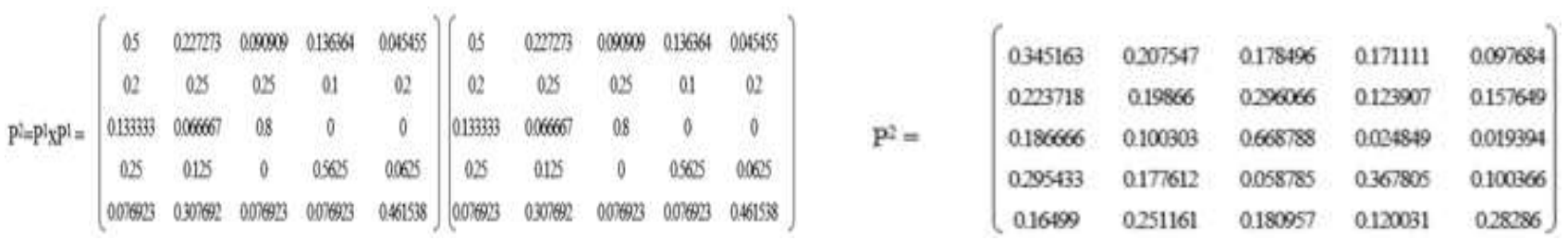

The results of the calculation of the matrix P2 above show that in the future the performance of the reporter Sofyan maintained the highest at 66.87 percent, followed by Pieter 36.78, and Maedop 34.51 percent.

The next analysis and calculation are carried out on the cameraman performance data, which is the data for the period I and period II is used to calculate the probability value, with the results as in the following table.

Table 14 Analysis and calculation are carried out on the cameraman performance data.

\begin{tabular}{|l|l|l|l|l|l|}
\hline Cameraman & Period II & \multicolumn{5}{l|}{ Jisnu } & Joidy & Arief \\
\hline Period I & Damian & Bagus & Wisnu & 0.074074 \\
\hline Damian & 0.296296 & 0.37037 & 0.148148 & 0.111111 & 0.058824 \\
\hline Bagus & 0.235294 & 0.352941 & 0.176471 & 0.176471 & 0.066667 \\
\hline Wisnu & 0.2 & 0.133333 & 0.6 & 0 & 0.067 \\
\hline Joidy & 0.266667 & 0.066667 & 0.066667 & 0.6 & 0.916667 \\
\hline Arief & 0.083333 & 0 & 0 & 0 & \\
\hline
\end{tabular}

The results of the table above can be rewritten in the form of a matrix P1 for the trend of cameraman performance as follows.

$$
\mathrm{P}=\left(\begin{array}{ccccc}
0.296296 & 037037 & 0.148148 & 0.111111 & 0.074074 \\
0235294 & 0352941 & 0.176471 & 0.176471 & 0.058824 \\
02 & 0.133333 & 0.6 & 0 & 0.066667 \\
0266667 & 0.06666 & 0.066667 & 06 & 0 \\
0.063333 & 0 & 0 & 0 & 0.916667
\end{array}\right)
$$

And to determine the trend of cameraman performance in the future, calculations are made to find out the value of P2 is as follows: 


\begin{tabular}{|c|c|c|c|c|c|c|c|c|c|c|c|c|c|c|c|}
\hline & OSEOS 0551 & 10 ons & 에메 & went & (10E) & 150 & พผล & 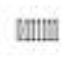 & corst & & 0240369 & 0267618 & 0205551 & 0.164948 & 0.121512 \\
\hline & 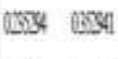 & 14. $11 \mathrm{XAl}$ & वासम & 醮 & 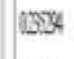 & 15XXI & 1509 & 1069 & (1) & & 0240017 & 0247007 & 0.21479 & 0.19431 & 0.103877 \\
\hline $\mathbb{R}^{\mathrm{P}}$ & 12 & 315 & 0 & ins & a & 0 & of & 1 & toffor & $\mathrm{P}^{2}=$ & 0216187 & 0201132 & 0.413159 & 0.045752 & 0.12377 \\
\hline & OE & 80 & If & 0 & oreter & Denter & 10 (1) & 15 & 0 & & 0268032 & 0.171184 & 0.131271 & 0.401394 & 0.028119 \\
\hline & $x=0$ & 0 & 0 & os & $x=$ & 0 & 1 & 1 & 6 & & 0.10108 & 0.030864 & 0.012346 & 0.009259 & socter \\
\hline
\end{tabular}

The results of the calculation of the P2 matrix above show that in the future the performance of Arief's cameraman the highest was 84.64 percent, followed by Wisnu with 41.31 percent, and Joidy at 40.13 percent.

\section{Conclusion}

Based on the results of this data warehouse research, the following conclusions can be drawn: 1. Initial implementation of a data warehouse to support television editorial decisions in Indonesia has been completed well, where Initial implementation this time was carried out at the Kompas TV editorial team, specifically collecting and processing performance data and news Kompas TV. 2. The results of the completed data warehouse can show the news trend in television editors where health news in particular the problem of the coronavirus or covid-19 occupies the highest position in the news, followed by economic and legal news which is if traced further still in the unity with health news. This result can be used by the chief editor of television to make strategic decisions regarding television coverage. 3 . The output from the television editorial data warehouse is also able to show the editorial team the best performance, starting from the best reporters, the best cameraman, to the best performing producer. These results can be input for the management or the chief editor of television to make decisions regarding career development and promotion.

This research can still be continued by developing data visualization related to television news coverage, especially the application of machine learning that reads and classifies news texts and also the application of business intelligence in television editors. Study and testing The initial implementation of this data warehouse also needs to be done to ensure that the data warehouse that is built is more appropriate with the needs and challenges faced by television editors.

\section{Compliance with ethical standards}

\section{Acknowledgments}

Praise and gratitude to God Almighty for all His mercy and grace so that this internal research has been completed. Not to forget, we would like to thank our family, the Universitas Mercu Buana, the Faculty Of Computer Science, and especially the PUSLIT Universitas Mercu Buana who have provided research funding support. The theme chosen in this internal research activity is "Designing E-Marketing Applications to Help Marketing Superior Village Products". The author realizes that this report is far from perfect, therefore criticism and constructive suggestions are expected to be better. Hopefully, this report can be of benefit to readers. Thank you.

\section{Disclosure of conflict of interest}

The authors declares that there is no conflict of interest in their research study.

\section{References}

[1] M Chevalier, M El Malki, A Kopliku, O Teste, R Tournier. Document-oriented models for data warehouses: NoSQL document-oriented for Data warehouses, in ICEIS 2016 - Proceedings of the 18th International Conference on Enterprise Information Systems. 2016.

[2] M Fotache, C Strimbei. SQL and Data Analysis. Some Implications for Data Analysits and Higher Education, Procedia Econ. Financ. 2015.

[3] RP Deb Nath, K Hose, TB Pedersen, O Romero. SETL: A programmable semantic extract-transform-load framework for semantic data warehouses, Inf. Syst. 2017.

[4] C Chen, J Liu, Q Li, Y Wang, H Xiong, S Wu. Warehouse site selection for online retailers in inter-connected warehouse networks, in Proceedings - IEEE International Conference on Data Mining, ICDM. 2017. 
[5] N Malhotra. Implementation of Data Marts in Data ware house, Int. J. Adv. Res. Ideas Innov. Technol. 2015.

[6] VM Ngo, NA Le-Khac, MT Kechadi. Designing and implementing data warehouse for agricultural big data, in Lecture Notes in Computer Science (including subseries Lecture Notes in Artificial Intelligence and Lecture Notes in Bioinformatics). 2019.

[7] G Garani, CE Atay. Encountering Incomplete Temporal Information in Clinical Data Warehouses, Int. J. Appl. Res. Public Heal. Manag. 2019.

[8] DC Hallin, C Mellado. Serving Consumers, Citizens, or Elites: Democratic Roles of Journalism in Chilean Newspapers and Television News, Int. J. Press. 2018.

[9] P Borah, E Fowler, TN Ridout. Television vs. YouTube: political advertising in the 2012 presidential election, J. Inf. Technol. Polit. 2018.

[10] P Lestari, DW Astari, AL Asyrafi. Audit of Disaster Communication on TVOne Kabar Petang Program, J. Komun. Ikat. Sarj. Komun. Indones. 2019.

[11] R Kannao, P Guha. Segmenting with style: detecting program and story boundaries in TV news broadcast videos, Multimed. Tools Appl. 2019.

[12] F Cherubini, RK Nielsen. Editorial Analytics: How News Media are Developing and Using Audience Data and Metrics, SSRN Electron. J. 2016.

[13] MG Yoedtadi, MA Pribadi. UPAYA REDAKSI TELEVISI MENJAGA OBJEKTIVITAS DALAM PEMBERITAAN PILKADA DKI JAKARTA, J. Muara Ilmu Sos. Humaniora, dan Seni. 2018.

[14] P Santoso, S Kholil, S Pohan. The Construction of the Reality of Coverage Media Television about the Islamic Defenders Front, Budapest Int. Res. Critics Inst. Humanit. Soc. Sci. 2019.

[15] JK Chalaby. Television and Globalization: The TV Content Global Value Chain, J. Commun. 2016.

[16] EK Suni. Analisis dan perancangan data warehouse untuk mendukung keputusan redaksi televisi menggunakan metode nine-step kimball, j. Tek. Inform. 2018.

[17] YS Triana, A Susilo. Aplikasi data warehouse untuk menunjang standar 3 borang akreditasi prodi informatika universitas mercu buana, J. Ilm. FIFO. 2017.

[18] R Rahutomo, RA Putri, B Pardamean. Building Datawarehouse for Educational Institutions in 9 Steps, in 1 st 2018 Indonesian Association for Pattern Recognition International Conference, INAPR 2018 - Proceedings. 2019.

[19] ZAS Abdullah, TAS Obaid. Design and Implementation of Educational Data Warehouse Using OLAP, IJCSN Int. J. Comput. Sci. Netw. 2016.

[20] I Ko, H Chang. Interactive visualization of healthcare data using Tableau, Healthc. Inform. Res. 2017.

[21] X Sun, W Sun, J Wang, Y Zhang, Y Gao. Using a Grey-Markov model optimized by Cuckoo search algorithm to forecast the annual foreign tourist arrivals to China, Tour. Manag. 2016.

[22] W Zucchini, IL Macdonald, R Langrock. Hidden Markov models for time series: An introduction using R, second edition. 2017.

[23] N Prakash, D Prakash, YK Sharma. Towards better fitting data warehouse systems," in Lecture Notes in Business Information Processing. 2009.

[24] E Malinowski, E Zimányi. A conceptual solution for representing time in data warehouse dimensions, in Conferences in Research and Practice in Information Technology Series. 2006.

[25] P Giorgini, S Rizzi, M Garzetti. Goal-oriented requirement analysis for data warehouse design, in DOLAP 2005 Proceedings of the 8th ACM International Workshop on Data Warehousing and OLAP, co-located with CIKM. 2005.

[26] A Vaisman, E Zimányi, A Vaisman, E Zimányi. Extraction, Transformation, and Loading, in Data Warehouse Systems. 2014.

[27] S George. Inmon vs. Kimball: Which approach is suitable for your data warehouse? Data Warehous. 2012.

[28] K Rose. Data on demand: A model to support the routine use of quantitative data for decision-making in Access Services," J. Access Serv. 2017. 
[29] D Pereira, P Oliveira, F Rodrigues. Data warehouses in MongoDB vs SQL Server: A comparative analysis of the querie performance. 2015.

[30] M Te Walvaart. Translating PSM Policy into Production Practices: Studying Newsroom Management Strategies towards Audience Engagement, VIEW J. Eur. Telev. Hist. Cult. 2019.

[31] S Rahayu, RA Sugihartono. STRATEGI PROGRAM HARD NEWS KOMPAS TV, Capture J. Seni Media Rekam. 2018.

[32] PJ Green. Reversible jump Markov chain monte carlo computation and Bayesian model determination, Biometrika. 1995. 